\title{
FORMULATION DEVELOPMENT AND EVALUATION OF PRESS COATED TABLETS OF MONTELUKAST SODIUM
}

\author{
Srilakshmi N*, P Sobhita Rani, Arun Kumar Das, T Neelima Rani \\ Malla Reddy Pharmacy College, Maisammaguda, Dhulapally, \\ Secunderabad-500014, T.S., India.
}

Corresponding Author e-mail: lakshmi.pharm@gmail.com

\begin{abstract}
:
An oral press-coated tablet was prepared by using direct compression method to achieve the predetermined lag time. This press-coated tablet containing montelukast sodium in the inner core was formulated with an outer barrier layer by different compositions of hydrophobic polymer ethylcellulose and hydrophilic polymer low-substituted hydroxyl propyl methyl cellulose. The effect of formulation composition on the barrier layer comprising both hydrophobic and hydrophilic excipients on the lag time of drug release was investigated. It was observed that lag time decreases with increasing concentration of low-substituted hydroxyl propyl methyl cellulose. Press coated tablets coated by dry mixing showed variations in lag time.
\end{abstract}

Key words: Press-coated tablet, lag time, ethylcellulose, low-substituted hydroxyl propyl methyl cellulose, pulsatile drug delivery.

\section{INTRODUCTION}

Compression coating or press-coating has been introduced during the period 1950-1960. The press coating technique is a simple and unique technology used to provide tablets with a programmable lag phase, followed by a fast, or rate-controlled, drug release after administration. The technique offers many advantages, and no special coating solvent or coating equipment is required for manufacturing this type of tablet. Pharmaceutical aspects of compression-coated tablets in dosage form development are to protect hygroscopic, light-sensitive, oxygen labile or acid-labile drugs, to separate incompatible drugs from each other and achieve sustained release, to modify drug release pattern. Accordingly, they draw increasing interest because of the inherent suitability for accomplishing chronotherapeutic goals, which have recently been highlighted in connection with a number of widespread chronic diseases with typical night or early morning recurrence of symptoms (e.g. bronchial asthma, cardiovascular disease, rheumatoid arthritis, early-morning awakening). ${ }^{[1]}$ Asthma is a chronic inflammatory disease of the airways, characterized by hyper responsiveness to a variety of stimuli. The role of circadian rhythms in the pathogenesis and treatment of asthma indicates that airway resistance increases progressively at night in asthmatic patients.

\section{How to cite this article:}

Srilakshmi N et. al., Formulation development and evaluation of press coated tablets of montelukast sodium. Int. J. Adv. Pharm. Biotech., 2015; 1(1): 45-53. 
Circadian changes are seen in normal lung function, which reaches a low point in the early morning hours. ${ }^{[2]}$ Circadian rhythms are selfsustaining, endogenous oscillations that occur with a periodicity of about 24 Hours. ${ }^{[3]}$

Circadian rhythm regulates many body functions in humans like metabolism, physiology, behavior, sleep pattern and hormone production. ${ }^{[4]}$ The worsening of asthma at night, commonly referred to as nocturnal asthma (NA). A drug delivery system administered at bedtime but releasing drug during morning hours would be ideal in this case. [5]. Consequently, the administration of a drug formulated in such a delivery system, i.e. taken at bedtime with a programmed start of drug release in early morning hours, could offer a more effective therapy than a typical controlled release drug delivery system, provided that the most appropriate drugs are administrated. [6] Pulsatile drug delivery system is the one type of drug delivery system, where the delivery device is capable of releasing drug after predetermined time-delay (i.e. lag time). Pulsatile drug delivery systems are gaining lot of interest and attention these days. These systems have a peculiar mechanism of delivering the drug rapidly and completely after a "lag time," i.e., a period of "no drug release".[7, 8]

Montelukast sodium is a cysteine leukotriene antagonist. It blocks the action of leukotriene D4 (and secondary ligands LTC4 and LTE4) on the cysteinyl leukotriene receptor $\mathrm{CysLT}_{1}$ in the lungs and bronchial tubes by binding to it. This reduces the bronchoconstriction and results in less inflammation and is used in the treatment of asthma.

The aim of this work is to develop modified drug release by using press coating technique with barrier coating by using hydrophilic and hydrophobic polymers such as HPMC and Ethyl cellulose with Montelukast sodium as model drug.

\section{MATERIALS AND METHODS}

Montelukast Sodium - model drug, was a gift sample from Sanzyme Pharmaceuticals, microcrystalline cellulose (MCC, Avicel PH102) was procured from Degussa India Pvt.
Ltd., Mumbai L.R. Crospovidone, Sodium starch glycolate, Cross-carmellose sodium (AcDi-Sol) and Sodium lauryl sulphate were purchased from S.D. Fine Chem. Ltd., Mumbai. Ethylcellulose (Ethocel) and Hydroxypropyl methylcellulose were purchased from L.R. Sisco Research Lab Pvt. Ltd., Mumbai. Magnesium stearate was purchased from Signet Chemical Corporation (Mumbai, India).

\section{Precompression Parameters}

The powder blend was evaluated for bulk density, tapped density, Carr's index, Hausner's ratio and angle of repose.

1. Bulk density $\left(D_{b}\right)^{[9]}$ : It is the ratio of total mass of powder to the bulk volume of powder. It was measured by pouring the weighed powder (passed through standard sieve \# 20) into a measuring cylinder and the initial volume was noted. This initial volume is called the bulk volume. From this, the bulk density is calculated according to the formula mentioned below. It expressed in $\mathrm{g} / \mathrm{cc}$ and is given by:

$$
\mathrm{D}_{\mathrm{b}}=\frac{\mathrm{M}}{\mathrm{V}_{0}}
$$

Where, $\mathrm{M}$ is the mass of powder,

$\mathrm{V}_{0}$ is the bulk volume of the powder.

2. Tapped density $\left(D_{t}\right)^{[9]}$ : It is the ratio of total mass of powder to the tapped volume of powder. The volume was measured by tapping the powder for 500 times. Then the tapping was done for 750 times and the tapped volume was noted (the difference between these two volumes should be less than $2 \%$ ). If it is more than $2 \%$, tapping is continued for 1250 times and tapped volume was noted. It is expressed in $\mathrm{g} / \mathrm{cc}$ and is given by:

$$
D_{t}=\frac{M}{V_{1}}
$$

Where, $M$ is the mass of powder,

$\mathrm{V}_{\mathrm{t}}$ is the tapped volume of the powder.

3. Carr's index (\%) [10]: The percentage compressibility (Carr's index) was calculated as 100 times the ratio of the difference between tapped density and bulk density to the tapped density.

$$
\text { Carr's index }=100 \mathrm{x} \frac{\text { Tapped density - Bulk density }}{\text { Tapped density }}
$$

4. Hausner's ratio: Hausner's ratio is the ratio of tapped density to bulk density. Lower 
the value of Hausner's ratio better is the flow property.

$$
\text { Hausner's Ratio }=\frac{\text { Tapped Density }}{\text { BulkDensity }}
$$

5. Angle of repose $(\theta)$ : It is defined as the maximum angle possible between the surface of a pile of powder and the horizontal plane.

$$
\theta=\tan ^{-1}(\mathrm{~h} / \mathrm{r})
$$

Where, $\theta$ is the angle of repose $\mathrm{h}$ is the height in $\mathrm{cm}$ $r$ is the radius in $\mathrm{cm}$ All the precompression parameters were shown in Table 1.

Table-1: Precompression Parameters

\begin{tabular}{cccccc}
\hline $\begin{array}{c}\text { Formulation } \\
\text { Code }\end{array}$ & $\begin{array}{c}\text { Bulk } \\
\text { Density }\end{array}$ & $\begin{array}{c}\text { Tapped } \\
\text { Density }\end{array}$ & $\begin{array}{c}\text { Compressibility } \\
\text { Index }^{\mathbf{a}}\end{array}$ & $\begin{array}{c}\text { Hausner } \\
\text { ratio }^{\mathbf{a}}\end{array}$ & $\begin{array}{c}\text { Angle of } \\
\text { Repose }^{\mathbf{a}}\end{array}$ \\
\hline F1 & $0.41 \pm 0.11$ & $0.501 \pm 0.04$ & $1.99 \pm 0.22$ & $16.57 \pm 1.20$ & $32 \pm 2.0$ \\
F2 & $0.42 \pm 0.10$ & $0.51 \pm 0.03$ & $1.21 \pm 0.23$ & $17.45 \pm 1.40$ & $36 \pm 2.0$ \\
F3 & $0.44 \pm 0.70$ & $0.49 \pm 0.03$ & $1.13 \pm 0.18$ & $11.60 \pm 1.50$ & $30 \pm 2.0$ \\
F4 & $0.45 \pm 0.90$ & $0.52 \pm 0.02$ & $1.15 \pm 0.15$ & $13.46 \pm 1.20$ & $27 \pm 1.0$ \\
F5 & $0.41 \pm 0.11$ & $0.49 \pm 0.05$ & $1.19 \pm 0.16$ & $16.29 \pm 2.20$ & $42 \pm 2.0$ \\
F6 & $0.42 \pm 0.13$ & $0.51 \pm 0.04$ & $1.21 \pm 0.28$ & $17.44 \pm 3.20$ & $36 \pm 1.0$ \\
F7 & $0.43 \pm 0.10$ & $0.49 \pm 0.51$ & $1.16 \pm 0.90$ & $13.82 \pm 1.40$ & $31 \pm 1.0$ \\
F8 & $0.39 \pm 0.90$ & $0.47 \pm 0.06$ & $1.20 \pm 0.80$ & $1702 . \pm 1.80$ & $29 \pm 2.0$ \\
F9 & $0.41 \pm 0.80$ & $0.46 \pm 0.07$ & $1.18 \pm 0.19$ & $16.40 \pm 0.90$ & $26 \pm 1.0$ \\
\hline
\end{tabular}

\section{Compatibility Studies}

Compatibility must be established between the active ingredient and other excipients to produce a stable, efficacious product. Accurately weighed quantity of drug and other excipients were mixed properly and one milligram of the sample was taken and mixed with $10 \mathrm{mg}$ of dried powered potassium bromide. These quantities are usually sufficient to give a disc of $10-15 \mathrm{~mm}$ diameter and pellet of suitable intensity by a hydraulic press. The powdered mixture was taken in a diffuse reflectance sampler and the spectrum was recorded by scanning in the wavelength region of IR 4000-400 $\mathrm{cm}^{-1}$ in FT-IR Spectrophotometer. The IR spectrum of the drug was compared with that of the mixture to check for any possible drug- excipients interaction and the results were shown in Fig. 1,2 and 3.

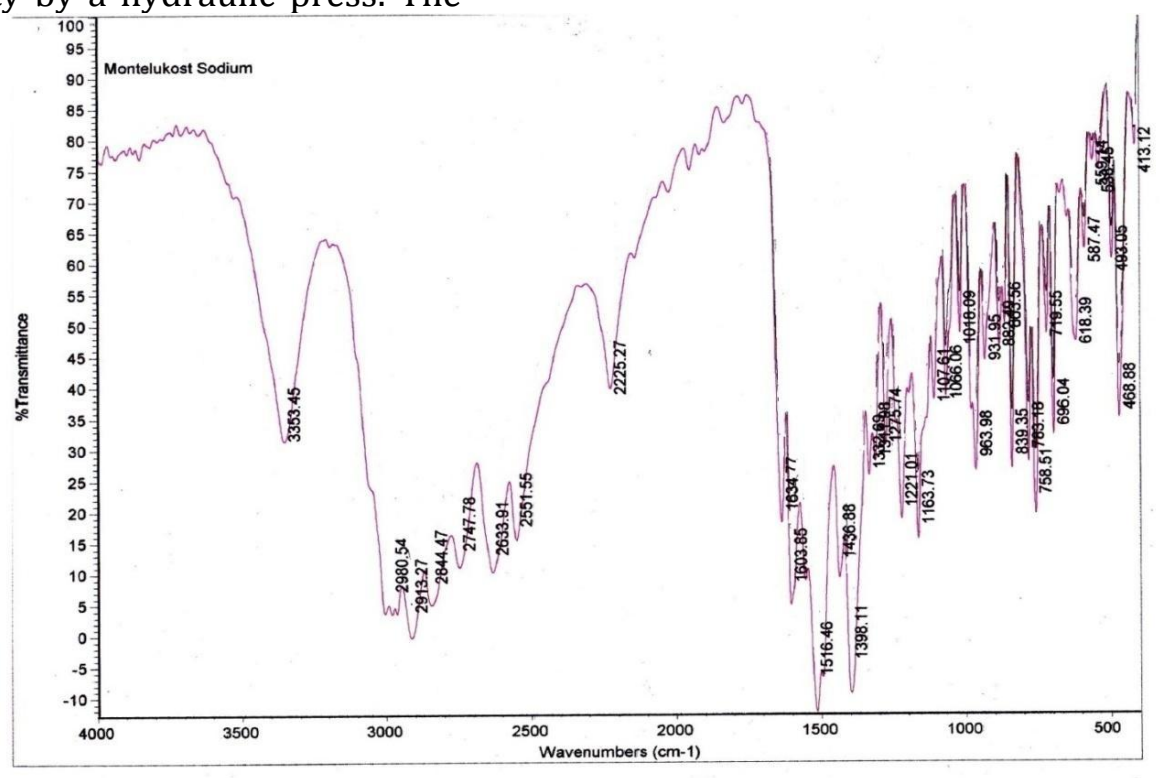

Fig. 1: FTIR spectrum of Montelukast sodium 


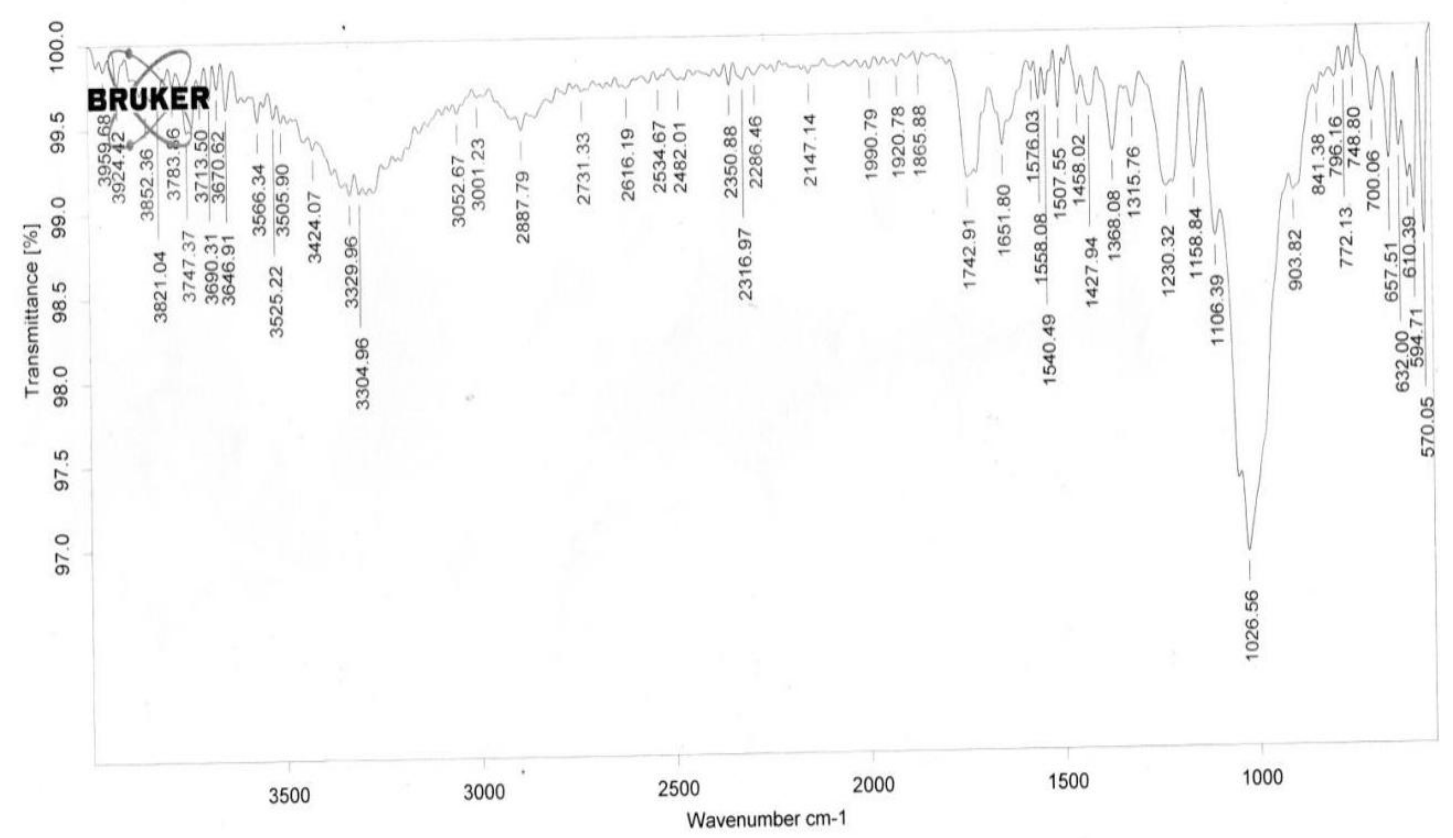

Fig. 2: FTIR spectrum of Montelukast sodium press coat

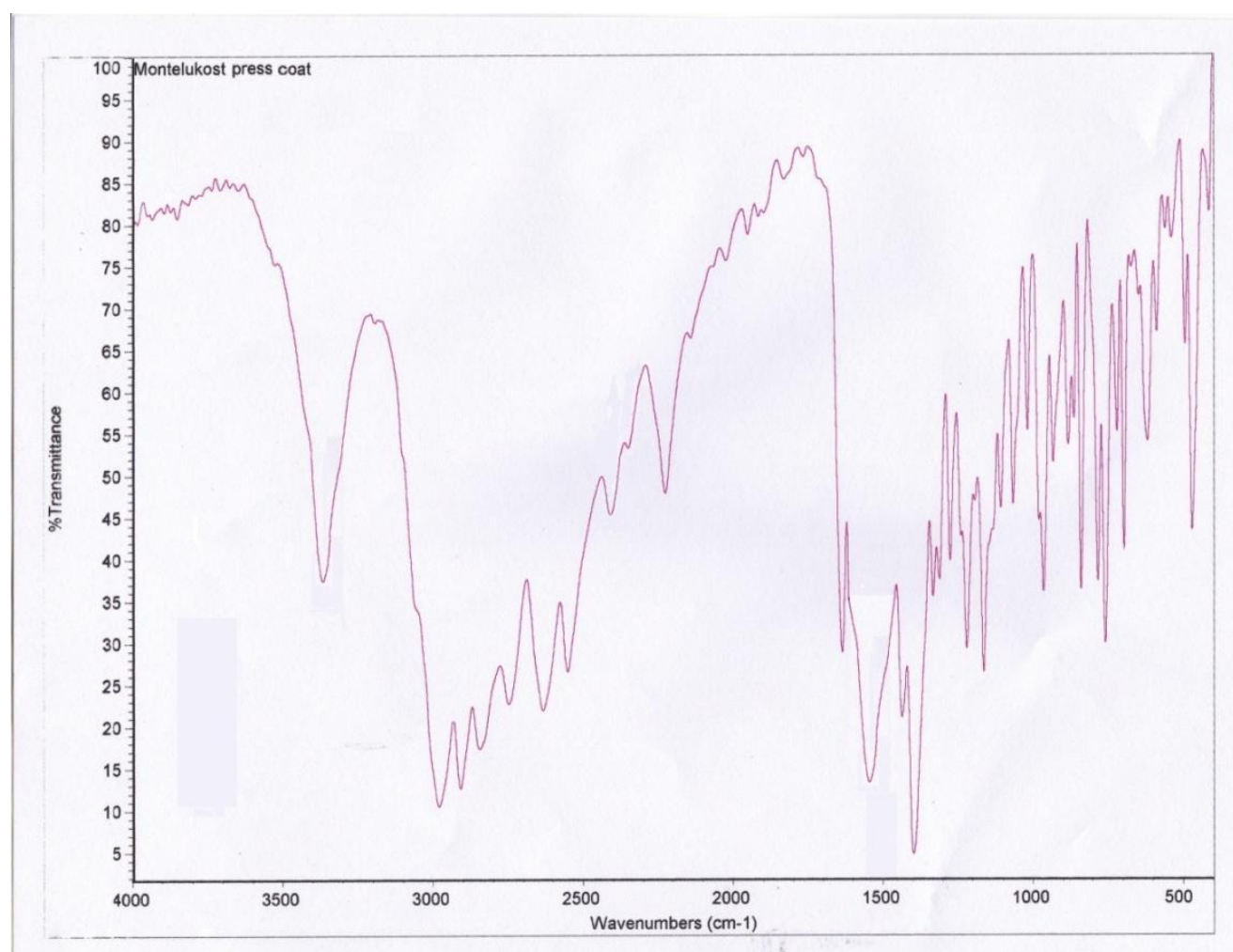

Fig. 3: FTIR spectrum of optimised Montelukast sodium press coat formulation

Determination of $\lambda_{\max }$ for Montelukast sodium:

$10 \mathrm{mg}$ of Montelukast sodium was dissolved in $10 \mathrm{ml}$ of $0.5 \%$ of SLS. From this different dilutions were prepared and the absorbance of prepared solution of Montelukast sodium was measured at $240 \mathrm{~nm}$ in UV/visible spectrophotometer against $0.5 \%$ of SLS solution as blank. The absorbance data for standard calibration curve was given in Fig. 4. 


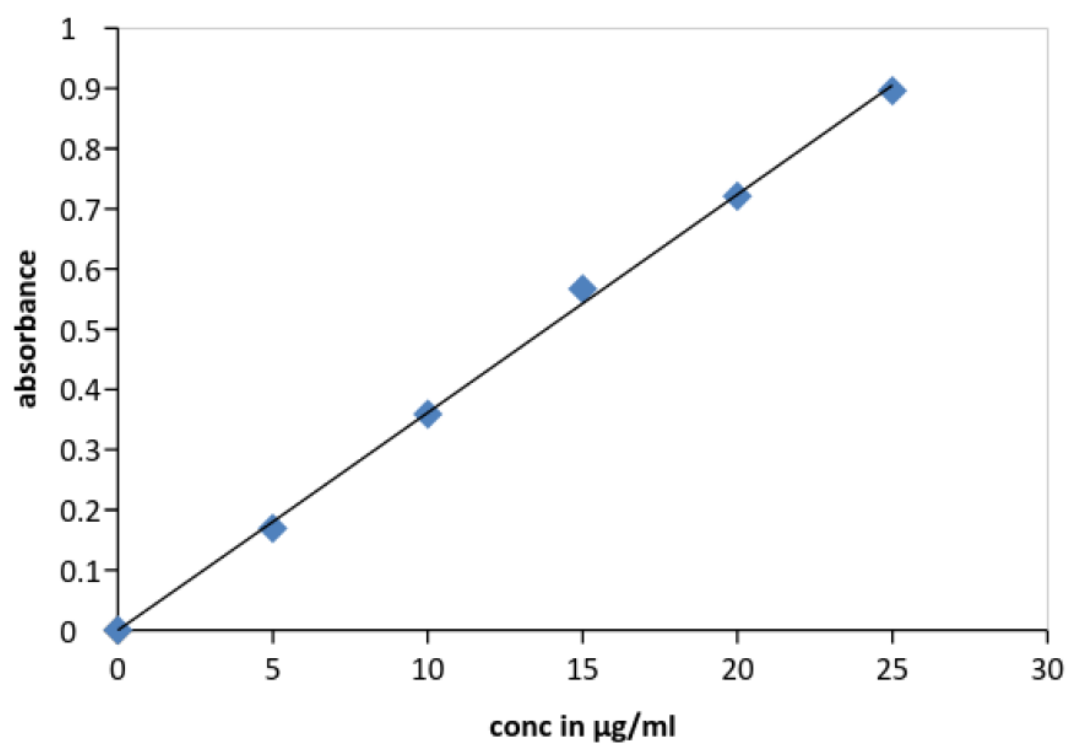

Fig. 4: Calibration curve of Montelukast sodium in 0.5\% SLS

Formulation Development:

Formulation of core tablets by direct compression:

The inner core tablets were prepared by direct compression method. The powder was dry blended for $20 \mathrm{~min}$ followed by addition of Magnesium Stearate. The mixtures were then further blended for 10 min. The resultant powder blend was compressed using $9 \mathrm{~mm}$ punch and die to obtain the core tablet. The compositions of core tablets are given in Table- 2 .

Table-2: Composition of core tablets

\begin{tabular}{|c|c|c|c|c|c|c|c|c|c|c|}
\hline S.No. & $\begin{array}{l}\text { Ingredients } \\
\text { (mg) }\end{array}$ & F 1 & F2 & F 3 & F 4 & F5 & F6 & F7 & F8 & F9 \\
\hline 1. & $\begin{array}{l}\text { Montelukast } \\
\text { sodium }\end{array}$ & 10 & 10 & 10 & 10 & 10 & 10 & 10 & 10 & 10 \\
\hline 2. & MCC & 158.9 & 154.4 & 149.9 & 158.9 & 154.4 & 149.9 & 158.9 & 154.4 & 149.9 \\
\hline 3. & Crospovidone & 9 & 13.5 & 18 & & & & & & \\
\hline 4. & $\mathrm{CCS}$ & & & & 9 & 13.5 & 18 & & & \\
\hline 5. & SSG & & & & & & & 9 & 13.5 & 18 \\
\hline 6. & $\begin{array}{l}\text { Magnesium } \\
\text { stearate }\end{array}$ & 1.8 & 1.8 & 1.8 & 1.8 & 1.8 & 1.8 & 1.8 & 1.8 & 1.8 \\
\hline \multirow[t]{2}{*}{7.} & SLS & 0.3 & 0.3 & 0.3 & 0.3 & 0.3 & 0.3 & 0.3 & 0.3 & 0.3 \\
\hline & Total wt & 180 & 180 & 180 & 180 & 180 & 180 & 180 & 180 & 180 \\
\hline
\end{tabular}

\section{Preparation of press-coated tablets:}

The core tablets were press-coated with $400 \mathrm{mg}$ of mixed blend as given in Table 3. Barrier layer material of $200 \mathrm{mg}$ was weighed and transferred into a $12 \mathrm{~mm}$ die then the core tablet was placed manually at the center. The remaining $200 \mathrm{mg}$ of the barrier layer material was added into the die and compressed at a pressure of 5 tons for $3 \mathrm{~min}$.
Table-:3 Composition of Press coat tablets

\begin{tabular}{cccccc}
\hline Press coat & P1 & P2 & P3 & P4 & P5 \\
\hline HPMC & 3 & 2 & 0 & 4 & 1 \\
Ethyl cellulose & 1 & 2 & 4 & 0 & 3 \\
Total wt (mg) & 400 & 400 & 400 & 400 & 400 \\
\hline
\end{tabular}




\section{RESULTS AND DISCUSSION:}

Evaluation of rapid release core tablets and press-coated tablets of Montelukast sodium:

1. Weight variation: Twenty tablets were randomly selected from each batch and weighed individually. The average weight and standard deviation was calculated and the results were given in Table $4 \& 5$.

2. Thickness: Three tablets from each batch of formulation were collected and the thicknesses of the tablets were measured with the help of Vernier caliper. The average thickness was calculated and the results were given in Table 4 $\& 5$.

3. Hardness: Hardness was measured using Monsanto tablet hardness tester. The hardness of five tablets in each batch was measured and the average hardness was calculated in terms of $\mathrm{kg} / \mathrm{cm}^{2}$ and the results were given in Table 4 $\& 5$.

4. Friability: Friability of the tablets was determined using Roche friabilator. Preweighted sample of tablets were placed in the friabilator and were subjected to 100 revolutions. Tablets were dusted using a soft muslin cloth and reweighed and the results were given in Table 4 \& 5 .
5. Wetting time: A piece of tissue paper folded twice was placed in a small petri dish containing $6 \mathrm{ml}$ of water. Tablet was kept on the paper and the time for complete wetting was measured. The results were tabulated in Table 4.

6. Swelling index: This test is for press coated tablets only. Two tablets from each batch were placed in a petri-dish with $2 \mathrm{ml}$ distilled water. The diameter of tablets was taken at intervals of five minutes until maximum diameter was attained with Digital Vernier calipers. Thereafter the swelling indices (SI) were calculated from initial diameter of tablet (D1) and maximum diameter on swelling in water (D2) as expressed below and the results were given in Table 5.

$$
\text { SI }(\%)=\text { D2/D1x } 100
$$

7. Disintegration time: To test the disintegration time of tablets, one tablet was placed in each tube and the basket rack was positioned in a 1 litre beaker at $37^{\circ} \mathrm{C} \pm 1^{\circ} \mathrm{C}$ such that the tablet remains $2.5 \mathrm{~cm}$ below the surface of the liquid. The time taken for the complete disintegration of the tablets was noted and the results were given in Table 4.

Table-4: Evaluation Parameters for Core Tablets

\begin{tabular}{ccccccccccc}
\hline S.No. & $\begin{array}{c}\text { Physical } \\
\text { parameter }\end{array}$ & F1 & F2 & F3 & F4 & F5 & F6 & F7 & F8 & F9 \\
\hline 1. & $\begin{array}{c}\text { Weight } \\
\text { variation(\%) } \\
\text { Hardness } \\
\text { (Kg/cm })\end{array}$ & 1.59 & 1.47 & 1.42 & 1.52 & 1.28 & 1.25 & 1.44 & 1.23 & 1.48 \\
2. & 4 & 4.2 & 4.3 & 4.1 & 4.3 & 4.4 & 4.2 & 4.3 & 4.4 \\
3. & $\begin{array}{c}\text { Thickness } \\
\text { (mm) }\end{array}$ & 3.25 & 3.22 & 3.24 & 3.24 & 3.4 & 3.50 & 3.20 & 3.18 & 3.26 \\
4. & $\begin{array}{c}\text { Friability \% } \\
\text { Disintegration } \\
\text { time (min) }\end{array}$ & 0.4 & 0.55 & 0.62 & 0.54 & 0.62 & 0.57 & 0.65 & 0.52 & 0.54 \\
6. & $\begin{array}{c}\text { Wetting time } \\
\text { (sec) }\end{array}$ & 52 & 55 & 52 & 48 & 48 & 50 & 50 & 45 & 54 \\
\hline
\end{tabular}


Table-5: Evaluation Parameters for Press Coated Tablets

\begin{tabular}{|c|c|c|c|c|c|c|}
\hline S.No. & $\begin{array}{c}\text { Physical } \\
\text { parameter }\end{array}$ & P1F8 & P2F8 & P3F8 & P4F8 & P5F8 \\
\hline 1. & $\begin{array}{c}\text { Weight } \\
\text { variation (\%) }\end{array}$ & 1.56 & 1.52 & 1.52 & 1.54 & 1.18 \\
\hline 2. & $\begin{array}{l}\text { Hardness } \\
\left(\mathrm{Kg} / \mathrm{cm}^{2}\right)\end{array}$ & 7.5 & 7.7 & 7.8 & 7.2 & 7.6 \\
\hline 3. & $\begin{array}{l}\text { Thickness } \\
\text { (mm) }\end{array}$ & 2.5 & 2.6 & 2.4 & 2.4 & 2.5 \\
\hline 4. & Friability \% & 0.56 & 0.55 & 0.62 & 0.54 & 0.62 \\
\hline 5. & $\begin{array}{l}\text { Swelling } \\
\text { index \% }\end{array}$ & 150 & 180 & 280 & 100 & 250 \\
\hline
\end{tabular}

8. In-vitro drug release studies: In -vitro dissolution studies of both core and coated tablets were done with the conventional paddle method at $50 \mathrm{rpm}$ using $0.5 \% \mathrm{w} / \mathrm{v}$ aqueous solution sodium lauryl sulfate at $37^{\circ} \mathrm{C} \pm 0.5^{\circ} \mathrm{C} .5$ $\mathrm{ml}$ of filtered aliquot was manually withdrawn at pre-determined time intervals and replaced with
$5 \mathrm{ml}$ of fresh $0.5 \%$ sodium lauryl sulfate solution maintained at the same temperature. The samples were analysed at $240 \mathrm{~nm}$ using a UV spectrophotometer. The lag time and percentage release was determined of the each formulation and the results were given in Fig. 5 and 6.

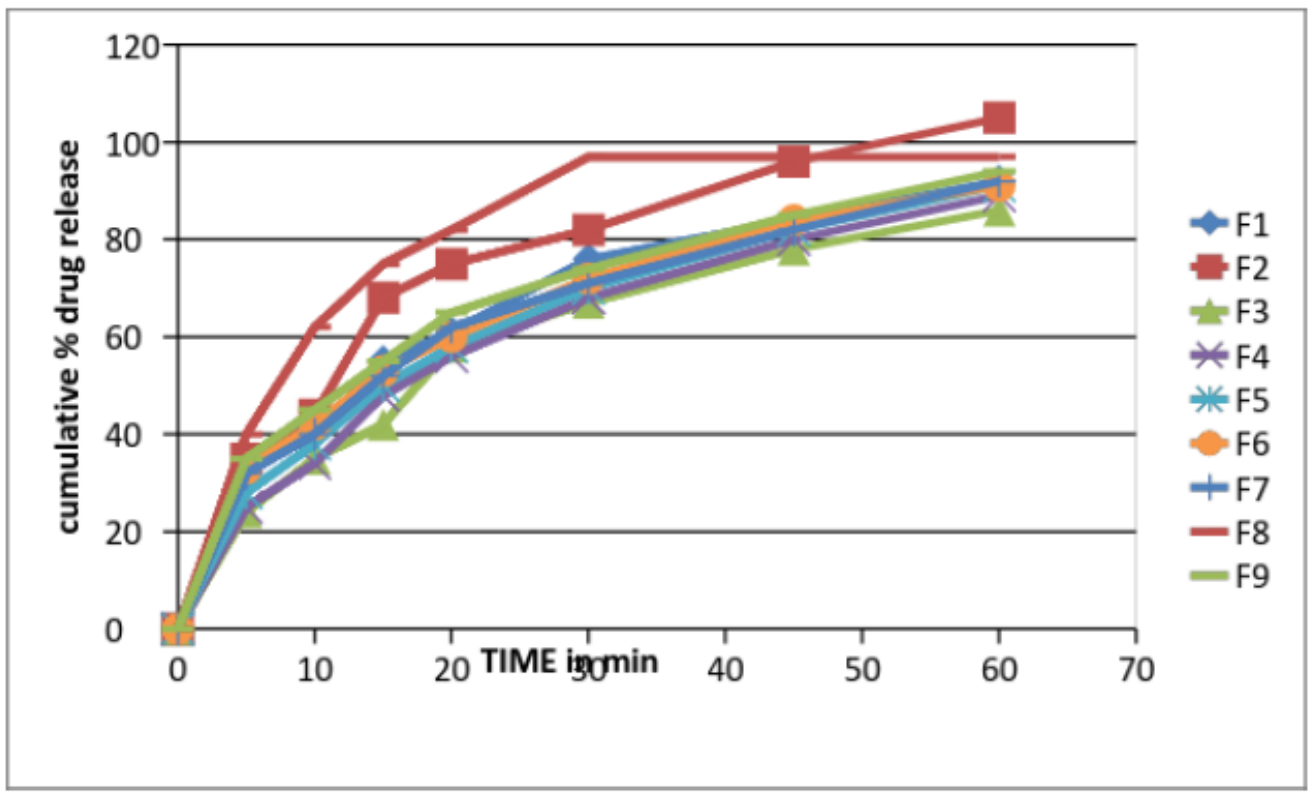

Fig. 5: Dissolution graph for core formulations F1-F9 


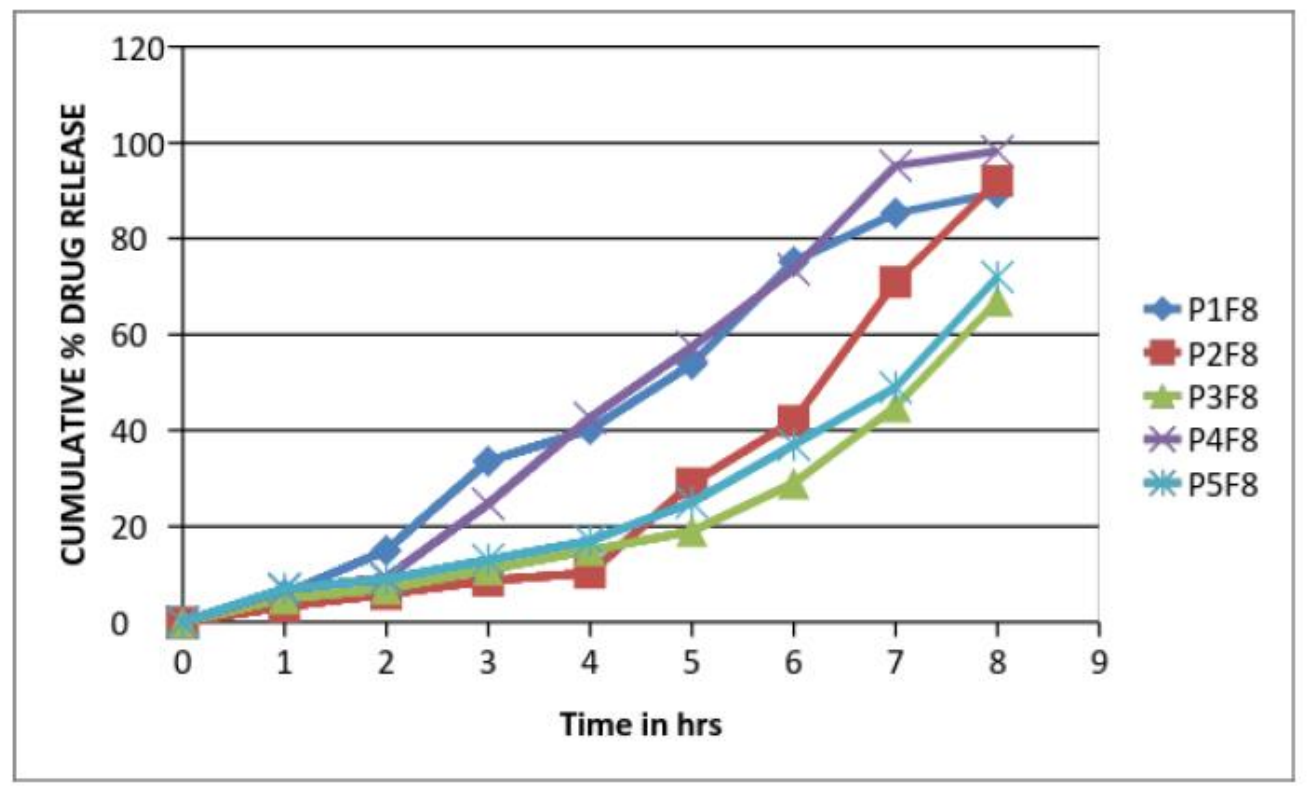

Fig. 6: Dissolution graph for press coated tablets of formulations

\section{Stability Studies:}

The stability studies of the formulations were carried out according to ICH guidelines at $25 \pm 2^{\circ}$ $\mathrm{C} / 60 \pm 5 \% \mathrm{RH}, 30 \pm 2^{\circ} \mathrm{C} / 75 \pm 5 \% \mathrm{RH}, 40 \pm 2^{\circ} \mathrm{C} / 75$ $\pm 5 \%$ RH for 90 days by storing the samples in stability chamber.
The purpose of stability testing is to provide evidence of the quality of the drug substance or drug product, and how it varies with time under the influence of a variety of environmental conditions (heat, humidity, light, air etc). Storage conditions were shown in Table- 6 and the results were shown in Table-7.

Table-6: Stability studies Storage conditions

\begin{tabular}{ccc}
\hline Study & Storage conditions & $\begin{array}{c}\text { Minimum time period covered } \\
\text { by data at submission }\end{array}$ \\
\hline Long term & $25 \pm 2^{\circ} \mathrm{C} / 60 \pm 5 \% \mathrm{RH}$ & 12 months \\
or & \\
Intermediate & $30 \pm 2^{\circ} \mathrm{C} / 75 \pm 5 \% \mathrm{RH}$ & 6 months \\
Accelerated & $40 \pm 2^{\circ} \mathrm{C} / 65 \pm 5 \% \mathrm{RH}$ & 6 months \\
\hline
\end{tabular}

Table-7: Stability Studies

\begin{tabular}{cccc}
\hline \multicolumn{4}{c}{ Cumulative \% drug release } \\
\hline $\begin{array}{c}\text { Sampling } \\
\text { interval }\end{array}$ & $\mathbf{2 5}^{\circ} \mathbf{C} / \mathbf{6 0 \% R H}$ & $\mathbf{3 0}^{\circ} \mathbf{C} / \mathbf{6 5 \%} \mathbf{R H}$ & $\mathbf{4 0}^{\circ} \mathbf{C} / \mathbf{7 5 \% R H}$ \\
\hline 0 Days & 92 & 92 & 92 \\
15 Days & 91.52 & 91.45 & 91.40 \\
30 Days & 90.82 & 90.75 & 90.70 \\
90 Days & 90.45 & 90.32 & 90.26 \\
\hline
\end{tabular}




\section{CONCLUSION:}

From the above experimental results it can be concluded that, formulated tablets gave satisfactory results for various physicochemical parameters like hardness, friability, thickness, weight variation. HPMC and Ethyl cellulose has predominant effect on the lag time, and also shown significant effect on drug release.

FT-IR studies revealed that there was no interaction between Montelukast sodium and the polymers. Press coated tablet shown a delayed release pattern. Among all the core tablet formulations, F8 was selected based on drug release within a given period of time. In-vitro release rate studies shown that the maximum drug release was observed in P2F8 and P4F8 formulations but P2F8 was optimized based on less amount of drug release during lag time. Formulations P2F8 found to be stable at $40^{\circ}$ $\mathrm{C} / 75 \% \mathrm{RH}$ for a period of 3 months.

\section{ACKNOWLEDGMENT}

The authors are thankful to Sanzyme Pharmaceuticals, for providing Montelukast Sodium, to Degussa India Pvt. Ltd. for providing Micro Crystaline Cellulose (PVP, K90), to S.D. Fine Chemicals (Mumbai, India) for providing Sodium Lauryl Sulfate, Crospovidone, Sodium Starch Glycolate, Cross Carmellose Sodium, to L.R. Sisco Reearch Lab for providing Hydroxy propyl methyl cellulose as gift samples.

\section{REFERENCES}

1. Satani R.R., Chotaliya M.B. and Raval M. Review on recent trends in press-coated pulse drug delivery system. International Bulletin of Drug Research, 2014; 4(6): 60-91.

2. Gothoskar A.V., Joshi A.M. and Joshi N. H. Pulsatile drug delivery systems: A review. Drug Del. Tech., 2004, 4(5): 207-211.

3. Jha N. and Bapat S. Chronobiology and chronotherapeutics. Kathmandu Uni. Med. J., 2004; 2(8): 384-388.

4. Arora S., Ali J., Ahuja A., Baboota S. and Qureshi J. Pulsatile drug delivery systems: An approach for controlled drug delivery. Ind. J. Pharm. Sci., 2006; 68: 295-300.

5. Skloot G. Nocturnal asthma: mechanisms and management. The Mount Sinai J. of Med., 2002; 69: 140-147.

6. Efentakis M., Koligliati S. and Vlachou M. Design and evaluation of a dry coated drug delivery system with an impermeable cup, swellable top layer and pulsatile release. Int. J. Pharm., 2006; 311: 147-156.

7. Basak S. C., Chronotherapeutics: Optimising drug delivery. Pharmebiz.com; August 17, 2005.

8. Janugade B.U. et. al., Formulation and evaluation of press-coated montelukast sodium tablets for pulsatile drug delivery system. Int. J. Chem. Tech. Res. 2009; 1(3): 690-691.

9. Cooper J. and Gunn C., Powder flow and compaction, In; Carter SJ, eds, Tutorial Pharmacy. New Delhi, India: CBS Publishers and distributors; 1986; 211-233.

10. Aulton ME, Wells TI, Pharmaceutics: The science of dosage form design, England: Churchill Livingstone; 1988. 